\title{
Distribution of Adjectives in Meiteilon
}

\author{
Maibam Somobala Devi \\ Centre for Applied Linguistics and Translation Studies, \\ University of Hyderabad, Hyderabad-500046, \\ Telangana, India
}

\begin{abstract}
The paper aims to present a detailed account of the distribution of Meiteilon adjectives in noun phrases as well as the differences in occurrence of different types of adjectives in the language. Meiteilon has two alternate word order for NP elements; A N NUM DEM and N A NUM DEM as adjectives can occur prenominally or postnominally. However, the adjective məča 'small' obligatorily occurs after the head noun.The paper shall show that the adjective məča 'small' is different from the other type of adjectives morphologically and syntactically.
\end{abstract}

Keywords: Meiteilon, adjectives, adjective distribution, noun phrase

\section{INTRODUCTION}

Meiteilon (the Meitei + lon 'language') is spoken basically in the state of Manipur which is in Northeastern India. It is also spoken in the neighbouring states namely Assam, Tripura, Mizoram, neighbouring countries namely Myanmar and Bangladesh by the Meitei inhabitants of these places. Meiteilon $\sim$ Meiteiron or Manipuri is a Tibeto- Burman language of Kuki-Chin sub-family (Grierson, 1904 vol. III part III). Meiteilon, a Tibeto-Burman language is a SOV, agglutinative language. Structurally, it is a head final language which shows left branching nodes in syntactic trees. It is also a tonal language. It is the most advanced Tibeto- Burman language having its own developed literary language and script (archaic script). Meiteilon is the lingua-franca of Manipur. Since 20 August 1992 Meiteilon becomes the first Tibeto- Burman language to receive recognition as a schedule VIII language of India.This paper examines the distribution pattern of adjectives in Meiteilon noun phrases. Adjectives can appear in two main types of syntactic contexts i.e., a) as attributive adjectives which directly modifies a noun and b) as predicative adjectives as the complement of a copula (Hofherr, 2010). This paper deals with the position of attributive adjectives inside the noun phrases.

\section{MEITEILON ADJECTIVES}

Meiteilon does not have a distinct word-class of adjectives. Most of the attributive adjectives are derived by the two respective rules i.e., i) prefix ' $ə$-'+stative verb root (monosyllabic)+ Nominalizer (NZR) suffix -bə $\sim$-pə' and ii) stative verb root (polysyllabic) + Nominalizer suffix '-bə $\sim-$ pə'.

i) Prefix ' $\partial$ ' - + monosyllabic root+ Nominalizer ' $-b \boldsymbol{o}^{\prime}$

(1) a. a -č̀w -bo lairik

PRF -big -NZR book

'big book'

b. o- pik -pə lairik

PRF small NZR book

'small book'

c. * ${ }^{*}-\quad p^{h} \partial \check{j}^{2} \quad-b \partial \quad$ lay

PRF- beauty -NZR flower

'beautiful flower'

Example (1) c is ungrammatical as the rule does not allow polysyllabic roots to combine with the prefix $\partial-$, as we can see the root $p^{h}$ ja is disyllabic hence the other rule can be applied to form adjective.

ii) Polysyllabic root + Nominalizer ' $-b$ ' $^{\prime}$

(2) a. $p^{h}$ วॅว -bə lay

beauty -NZR flower

'beautiful flower' 


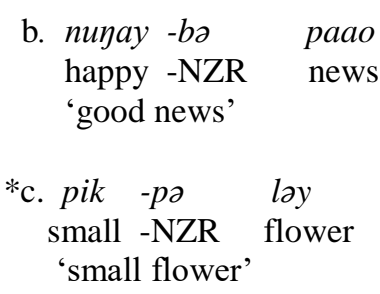

As we have seen in (1) a and $b$, the monosyllabic stative verb roots combine with prefix $\partial$ - to form adjectives therefore, example (2) c is ungrammatical.

\section{DISTRIBUTION OF MEITEILON ADJECTIVES INSIDE THE NOUN PHRASE}

Meiteilon has two alternate word order for NP elements; A N NUM DEM and N A NUM DEM as Meiteilon adjectives can occur prenominally and postnominally. Attributive adjectives which are derived by the two respective rules can occur prenominally or postnominally as shown in (3) - (4):

\section{Prenominal adjectives}

$$
\begin{aligned}
& \text { (3) a. ə-čaw-bo layrik ani si } \\
& \text { big book two DEM } \\
& \text { 'These two big books' } \\
& \text { b. phy̆a-bo loy oni si } \\
& \text { beautiful flower two DEM }
\end{aligned}
$$

'These two beautiful flowers'

\section{Postnominal adjectives}

(4) a. layrik o-čəw-bə oni si big book two DEM

'These two big books'

$$
\begin{aligned}
& \text { b. lay phəјə-bə əni si } \\
& \text { flower beautiful two DEM } \\
& \text { 'These two beautiful flowers' }
\end{aligned}
$$

Greenberg's (1966) universal 18 suggests that, if adjectives precede the noun then demonstratives and numerals should also precede the noun as stated bellow:

\section{Greenberg's universal 18:}

When the descriptive adjective precede the noun, the demonstrative and numeral, with overwhelmingly more than chance frequency, do likewise.

However in the case of Meiteilon, only adjectives can precede the noun not the other modifiers. Also according to Greenberg's (1966) universal 20, if the modifiers (demonstrative, numeral and descriptive adjectives) precede the noun they should be in the order of DEM NUM A N and if they follow the noun, it should be either the same as above; N DEM NUM A or its exact opposite i.e. N A NUM DEM, as stated bellow:

\section{Greenberg's Universal 20:}

When any or all of the items (demonstrative, numeral and descriptive adjectives) precede the noun they are always found in that order. If they follow, the order is either the same or the exact opposite.

Meiteilon noun phrases with postnominal adjective follows the universal 20 and follows the order of $\mathrm{N}$ A NUM DEM as in (4). However, the noun phrases with prenominal adjectives do not follow the orders given above as they precede the head noun and other modifiers follows the noun. It comes out with the order of $\mathrm{A} \mathrm{N}$ NUM DEM respectively as we can see from the above example (3). About 20 years later Hawkins (1983) reformulated Greenberg's universal 20 as some languages are found to be deviated from the above mentioned possible orders for the modifiers which follows the noun i.e. [N A NUM DEM] and [N DEM NUM A] . Some languages also have other order i.e. Aghem [N A DEM NUM], Noni [N DEM NUM A] and [N DEM A NUM ]. Thus he reformulated Greenberg's universal 20 and stated as follows: 
Universal 20': When any or all of the items (demonstrative, numeral and descriptive adjectives) precede the noun, they (i.e. those that do precede) are always found in that order. For those that follow, no predictions are made, though the most frequent order is the mirror-image of the order for preceding modifiers. In no case the adjective precede the head when the demonstrative or numeral follows

Even this reformulated version of universal does not explain the prenominal adjective order in Meiteilon noun phrase, as this also restricted the adjective to precede the noun allone and the other modifiers follow the noun. However, according to Cinque (2005) this order can be attested. And these orders inside DP can be explained if we adopt the theory of raising $\mathrm{N}$ to higher functional heads (detailed theory available in Cinque 2005). On the basis of careful typological work, he argues that of the twenty-four logically possible orders of these elements, only fourteen are attested as unmarked word orders in natural languages. The typological pattern is illustrated below:
a.
(i) DEM NUM A N
attested
(ii) DEM NUM N A
attested
(iii) DEM N NUM A
attested
(iv) N DEM NUM A
attested
b. (i) DEM A NUM N
unattested
(ii) DEM A N NUM
attested
(iii) DEM N A NUM
attested
(iv) N DEM A NUM
attested
c.
(i) NUM DEM A N
unattested
(ii) NUM DEM N A
unattested
(iii) NUM N DEM A
unattested
(iv) N NUM DEM A
unattested
d.
(i) NUM A DEM N
unattested
(ii) NUM A N DEM
attested
(iii) NUM N A DEM
attested
(iv) N NUM A DEM
attested
e.
(i) A DEM NUM N
unattested
(ii) A DEM N NUM
unattested
(iii) A N DEM NUM
attested
(iv) N A DEM NUM
attested
f. (i) A NUM DEM N
(ii) A NUM N DEM
(iii) A N NUM DEM
unattested
unattested
(iv) N A NUM DEM
attested
attested

(Adapted from Cinque 2005)

It is evident that by raising $\mathrm{N}$ to higher functional heads the above mentioned 14 unmarked orders can be explained in the natural languages. The alternate word order for NP elements; A N NUM DEM and N A NUM DEM which is f (iii) and (iv) the list is found in Meiteilon noun phrases.

\section{Exceptional case of adjective məča 'small'}

Meiteilon adjective $m ə \check{c} a$ 'small' (considered as an adjective due to its meaning) differs from the above discussed adjectives which are derived from the two respective rules. It does not follow any of the formation rules and it is an independent adjective. Where the other two types of adjectives can occur prenominally or postnominally but the adjective məča 'small' has a fixed postnominal position inside the noun phrase. Consider the examples bellow:

(5) a. layrik moča
book small
'small book'

*b. məča layrik 
small book

'small book'

\section{Distribution of more than one adjective}

As we have seen in 3, Meiteilon adjectives can occur prenominally or postnominally. They can be moved around the noun without causing any ungrammaticality as we have seen in (3) and (4). Now we will examine the distribution of more than one adjective inside the noun phrases.

(6) a. nuysi-bə a-you-bə a-pik-bə huy ani si

cute white small dog two DEM

'These two small white cute dogs'

b. ə-you-bə a-pik-pa nuysi-bo huy ani si

white small cute dog two DEM

'These two small white cute dogs'

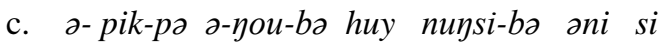

small white dog cute two DEM

'These two small white cute dogs'

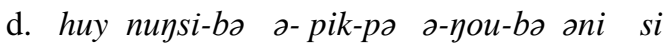

dog cute small white two DEM

'These two small white cute dogs'

The above examples show that adjectives can be moved around the noun as well as the other adjectives. They do not have any restrictions in movements. The adjective məča cannot move around the noun, however the N+Adj $(m ə \check{c} a)$ can move around the adjectives. Consider the examples given bellow:

(7) a. nuysi-bə ə-you-bə huy məča əni si

cute white dog small two DEM

'These two small white cute dogs'

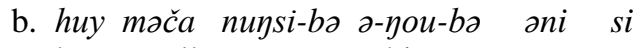

dog small cute white two DEM

'These two small white cute dogs'

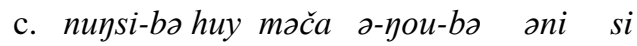

cute dog small white two DEM

'These two small white cute dogs'

*d. nuysi-bə huy a-you-bə məс̆a әni si

cute dog white small two DEM

'These two small white cute dogs'

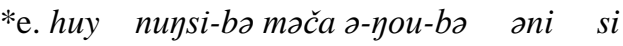

dog cute small white two DEM

'These two small white cute dogs'

Thus, it is evident that adjective $m ə \check{c} a$ is different from the other adjectives morphologically and syntactically. Meiteilon has another adjective 'ə-pik-pə' which has the same meaning of məča 'small' and which is derived by the rule (1) and can occur prenominally or post nominally. The question here is that if $m ə \check{c} a$ ' $\mathrm{sm}$ all' is an adjective then why it is different from the other adjectives in terms of formation and syntactic occurrence? Is this exceptional word an adjective or other noun modifying words? The further research will be

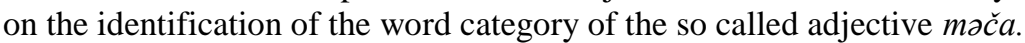




\section{CONCLUSION}

The paper mainly discussed about the position of adjectives inside the Meiteilon noun phrases. Meiteilon adjectives are derived from state verbs by two respective rules, - - + monosyllabic verb root+ - ba and polysyllabic state verb root $+-b ə$ and they can occur prenominally or postnominally therefore Meiteilon has two alternate word order for NP elements; A N NUM DEM and N A NUM DEM. And these two alternate word order can be explained by adopting Cinque (2005)'s $\mathrm{N}$ movement to the higher functional heads. In addition to this, adjectives can move around the adjectives where a noun phrase has more than one adjective, there is no restriction on occurrences. In contrast to the above two types of adjective, mača is an independent adjective and cannot apply any of the adjective formation rules and has a fix postnominal position. And the fix N+Adj (məča) combination can move around the adjectives. From this paper the further questioned has raised i,e,. if məča 'small' is an adjective then why it is different from the other adjectives in terms of formation and syntactic occurrence? Therefore the further research is required to examine the nature of məča and identify the word category.

$\begin{array}{ll}\text { A } & \text { adjective } \\ \text { DEM/Dem } & \text { demonstratives } \\ \mathrm{N} & \text { noun } \\ \mathrm{NP} & \text { noun pharse } \\ \mathrm{NUM} & \text { number } \\ \mathrm{NZR} & \text { nominalizer } \\ \text { PRF } & \text { prefix }\end{array}$

\section{ABBREVIATIONS}

\section{REFRENCES}

[1] Cinque, Guglielmo. 2005. Deriving Greenberg's Universal 20 and Its Exceptions. Lingusitic Inquiry, Vol.36, No.3, 315-332.

[2] Greenberg, Joseph H.1966. Some Universals of Grammar with Particular Reference to the Order of Meaningful Elements. Universals of Language, ed. By J.H Greenberg. Cambridge, Massachusets, and London, England: MIT Press. 73-113.

[3] Hofherr, Patrica Cabredo. 2010. Adjectives- an Introduction. In Adjectives- Formal analyses in syntax and semantics. Cabredo Hofherr, Patrica \& Ora Matusshanky (eds). Amsterdam:John Benjamin. 